\title{
Sensitivity of the Weddell Sea sector ice streams to sub-shelf melting and surface accumulation
}

\author{
A. P. Wright ${ }^{1}$, A. M. Le Brocq ${ }^{1}$, S. L. Cornford ${ }^{2}$, R. G. Bingham ${ }^{3}$, H. F. J. Corr ${ }^{4}$, F. Ferraccioli ${ }^{4}$, T. A. Jordan ${ }^{4}$, \\ A. J. Payne ${ }^{2}$, D. M. Rippin ${ }^{5}$, N. Ross ${ }^{6}$, and M. J. Siegert ${ }^{7}$ \\ ${ }^{1}$ Geography, College of Life and Environmental Sciences, University of Exeter, Exeter EX4 4RJ, UK \\ ${ }^{2}$ Bristol Glaciology Centre, School of Geographical Sciences, University of Bristol, Bristol BS8 1SS, UK \\ ${ }^{3}$ School of Geosciences, University of Edinburgh, Edinburgh EH8 9XP, UK \\ ${ }^{4}$ British Antarctic Survey, Madingley Road, High Cross, Cambridge, Cambridgeshire CB3 0ET, UK \\ ${ }^{5}$ Environment Department, University of York, Heslington, York YO10 5DD, UK \\ ${ }^{6}$ School of Geography, Politics and Sociology, Newcastle University, Newcastle Upon Tyne NE1 7RU, UK \\ ${ }^{7}$ Grantham Institute and Department of Earth Science and Engineering, Imperial College London, \\ South Kensington, London SW7 2AZ, UK
}

Correspondence to: S. L. Cornford (s.1.cornford@bristol.ac.uk)

Received: 4 July 2013 - Published in The Cryosphere Discuss.: 19 November 2013

Revised: 16 July 2014 - Accepted: 18 September 2014 - Published: 24 November 2014

\begin{abstract}
A recent ocean modelling study indicates that possible changes in circulation may bring warm deep-ocean water into direct contact with the grounding lines of the Filchner-Ronne ice streams, suggesting the potential for future ice losses from this sector equivalent to $\sim 0.3 \mathrm{~m}$ of sealevel rise. Significant advancements have been made in our knowledge of both the basal topography and ice velocity in the Weddell Sea sector, and the ability to accurately model marine ice sheet dynamics, thus enabling an assessment to be made of the relative sensitivities of the diverse collection of ice streams feeding the Filchner-Ronne Ice Shelf. Here we use the BISICLES ice sheet model, which employs adaptive-mesh refinement to resolve grounding line dynamics, to carry out such an assessment. The impact of realistic perturbations to the surface and sub-shelf mass balance forcing fields from our 2000-year "reference" model run indicate that both the Institute and Möller ice streams are highly sensitive to changes in basal melting either near to their respective grounding lines, or in the region of the ice rises within the Filchner-Ronne Ice Shelf. These same perturbations have little impact, however, on the Rutford, Carlson or Foundation ice streams, while the Evans Ice Stream is found to enter a phase of unstable retreat only after melt at its grounding line has increased by $50 \%$ of likely present-day values.
\end{abstract}

\section{Introduction}

A recent geophysical survey (see e.g. Ross et al., 2012) has highlighted the potential for a marine ice sheet instability (e.g. Mercer, 1978) at both the Institute and Möller ice streams in the Weddell Sea sector of West Antarctica. Near to the grounding lines of these ice streams, the bed topography has been observed to deepen significantly inland (a configuration often called a reverse slope), and also to be smooth, with few potential pinning points (Ross et al., 2012). While these ice streams currently show no signs of the dynamicthinning behaviour that has been observed in the Amundsen Sea region (Payne et al., 2004; Joughin et al., 2010; Pritchard et al., 2012), ocean modelling studies suggest that changes to current circulation patterns may result in greater melting at the base of the Filchner-Ronne Ice Shelf (Hellmer et al., 2012). Such changes have the potential to affect the tributary ice streams and therefore the parent ice mass. In this paper we employ an ice sheet model to investigate the possibility that thinning of the Filchner-Ronne Ice Shelf, and the consequent reduction of buttressing at the grounding lines of its tributary ice streams, could lead to the loss of grounded ice (cf. the Larsen B Ice Shelf collapse; Scambos et al., 2004).

Analysis of the new basal topography from airborne radioecho sounding has revealed the significance of a subglacial basin (recently named the Robin Subglacial Basin) which 


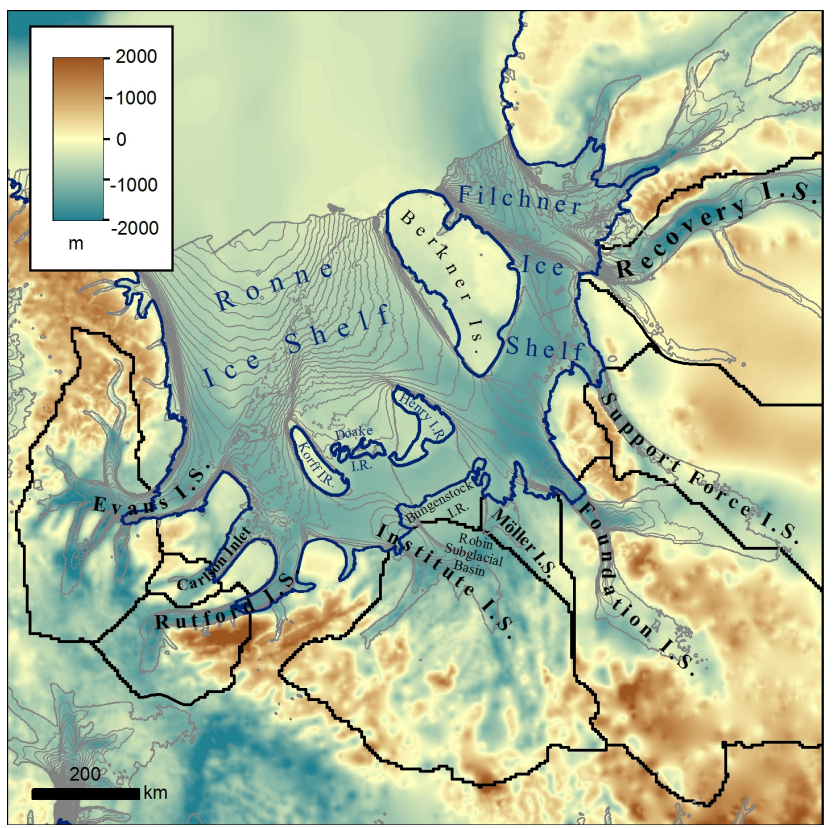

Figure 1. Catchments of the Filchner-Ronne Ice Shelf tributaries, shown overlain on the Bedmap2 bed topography (colour scale) used in this study. Ice velocity from Rignot et al. (2011) is indicated by grey contours at $50 \mathrm{~m} \mathrm{a}^{-1}$ intervals.

has a depth of around $1600 \mathrm{~m}$ b.s.l. at a distance less than $100 \mathrm{~km}$ upstream from the grounding lines of both the Institute and Möller ice streams (Ross et al., 2012). These ice streams currently discharge into the ice shelf on either side of the Bungenstock Ice Rise, where the bed elevation is around $1150 \mathrm{mb}$ b.s.l. (Fig. 1). The reverse bed slopes along both glacier trunks are therefore comparable to that beneath Thwaites Glacier. The ice stream surface gradients, however, are much shallower on the tongues of the Institute and Möller ice streams than they are in the Amundsen Sea, thus implying that the bed in this area is able to support significantly lower driving stresses (Joughin et al., 2006; Ross et al., 2012). Radio-echo sounding also suggests that the bed of the Robin Subglacial Basin is covered with marine sediments, deposited during past retreat phases associated with periods of warmer climate. Several linear, glacially eroded basal troughs are found upstream of the basin, each of which ends in a raised bar indicative of a former ice sheet margin $\sim 200 \mathrm{~km}$ upstream from the present-day grounding line (Ross et al., 2014). These interpretations, along with evidence from sea floor sediment analyses (Naish et al., 2009) and ice sheet modelling of multiple glacial cycles (Pollard and DeConto, 2009), support the idea that the West Antarctic Ice Sheet has, under warmer past climates, been confined to a stable position occupying the highlands upstream from the currently glaciated basin beneath the trunks of the Institute and Möller ice streams. Future climate warming, therefore, may risk a return of the ice sheet to this configuration.
Several modelling studies (e.g. Payne et al., 2004; Dupont and Alley, 2005; Joughin et al., 2010) and a growing body of observational evidence (Pritchard et al., 2012) suggest that the thinning of ice shelves, and the consequent decrease in buttressing at the mouths of fast-flowing ice streams, is the main cause of the observed dynamic thinning identified in the Amundsen Sea Embayment region of West Antarctica. The high basal melt rates observed beneath the Pine Island Ice Shelf are thought to be due to the incursion of warm Circumpolar Deep Water along channels which cross-cut the continental shelf (Jacobs et al., 1996). In the Weddell Sea sector, High-Salinity Shelf Water (HSSW) is currently responsible for melting at the grounding lines of the ice streams feeding the Filchner-Ronne Ice Shelf. This water mass is cooler than the Circumpolar Deep Water but it is still warm enough to cause melt rates of between 0.1 and $2.5 \mathrm{~m} \mathrm{a}^{-1}$ near to the grounding line of Rutford Ice Stream (Jenkins et al., 2006). Recent predictions of ocean circulation models indicate, however, that relatively modest future climate warming might result in changes to circulation patterns in the Southern Ocean that would allow warmer deep-ocean water to penetrate across the continental shelf in this area (Hellmer et al., 2012). If this were to happen then melt rates at the grounding lines of the Filchner-Ronne tributaries would be expected to increase by an order of magnitude (Hellmer et al., 2012), towards values currently found only in the Amundsen Sea sector (Rignot and Jacobs, 2002).

The Institute and Möller ice streams are separated by the slow-flowing Bungenstock Ice Rise; both ice streams have a "grounding zone" around $10 \mathrm{~km}$ wide where the grounded ice plain is floated for a period either side of high tide (Brunt et al., 2011). The steep reverse bed slopes, coupled with the low basal roughness (and therefore few pinning points) of both the Institute and Möller ice streams, suggest intuitively that even a small increase in melt at the grounding line, or a decrease in buttressing due to thinning of the ice shelf, may lead to a speed-up and thinning of the already lightly grounded ice plains, resulting in flotation and possibly unstable retreat of the grounding line.

Theoretical work has concluded that an idealised marine ice sheet that does not vary in the direction transverse to ice flow will be inherently unstable when the grounding line rests on a reverse bed slope (Schoof, 2007). When the problem is extended to realistic cases with two horizontal dimensions, however, drag from the channel sides as well as the buttressing effect of ice shelves is found to have a stabilising effect on grounding line dynamics even on a reverse bed slope (Dupont and Alley, 2005; Goldberg et al., 2009; Gudmundsson et al., 2012; Gudmundsson, 2013). Geophysical evidence also suggests that the stability of palaeo-ice-stream grounding line locations on reverse slopes has been dependent on the channel width available, with constrained channels slowing retreat substantially (Jamieson et al., 2012).

In addition to changes in ocean warming and circulation, anthropogenic climate change is also expected to cause 
changes to precipitation patterns and, in Antarctica, warmer air temperatures are likely to mean an increase in surface snow accumulation (e.g. Uotila et al., 2007; Winkelmann et al., 2012), which could mitigate some melt-driven retreat. The aim of this paper is to assess the sensitivity of the various Filchner-Ronne Ice Shelf tributary ice streams to sub-shelf melt/freeze-rate and surface accumulation perturbations of the order of those predicted to occur within the next few hundred years given certain scenarios (e.g. Hellmer et al., 2012). The model is run over a period of 2000 years in order to investigate the full response of the ice sheet to the perturbations, whilst balancing the assumptions made when setting up the domain and boundary conditions and the computational time of the model. The variations in geometry, basal topography, catchment area, grounding line melt rate and location with respect to ice rises within the ice shelf suggest that the responses of the different ice streams in this sector may differ substantially. In this paper we aim to make an assessment of those differences and of their causes.

\section{The BISICLES ice sheet model}

\subsection{Model description}

We use the BISICLES ice sheet model, a detailed description of which is given in Cornford et al. (2013). BISICLES is a finite-volume model which applies a two-dimensional force balance approximation approach to the solution of the Stokes free-surface problem with the addition of a vertically integrated stress component derived from the model of Schoof and Hindmarsh (2010) following

$\nabla \cdot[\phi h \bar{\mu}(2 \dot{\boldsymbol{\epsilon}}+2 \operatorname{tr}(\dot{\boldsymbol{\epsilon}}) \mathbf{I})]+\boldsymbol{\tau}^{b}=\rho_{\mathrm{i}} g h \nabla s$,

where $\phi$ is a stiffening or "damage" factor, $h$ is the ice thickness, $\bar{\mu}$ is the vertically averaged viscosity, $\dot{\boldsymbol{\epsilon}}$ is the horizontal rate-of-strain tensor, $\mathbf{I}$ is the identity tensor, $\boldsymbol{\tau}^{b}$ is the basal traction, $\rho_{\mathrm{i}}$ is the density of ice, $g$ is acceleration due to gravity and $s$ is the ice surface. The horizontal rate-of-strain tensor is given by

$\dot{\boldsymbol{\epsilon}}=\frac{1}{2}\left[\nabla \boldsymbol{u}+(\nabla \boldsymbol{u})^{T}\right]$,

where $\boldsymbol{u}$ is the horizontal ice velocity. The vertically integrated effective viscosity $(\phi h \bar{\mu})$ is computed from the vertically varying effective viscosity $\mu$ :

$\phi h \bar{\mu}(x, y)=\phi \int_{s-h}^{s} \mu(x, y, z) \mathrm{d} z$,

where $\mu$ includes a contribution from vertical shear and satisfies

$2 \mu A(T)\left(4 \mu^{2} \dot{\epsilon}^{2}+\left|\rho_{\mathrm{i}} g(s-z) \nabla s\right|^{2}\right)^{(n-1) / 2}=1$, where $n$ is the flow rate exponent $(n=3)$ and $A$ is the iceflow rheological parameter. $A$ is calculated as a function of ice temperature $(T)$ using the relation formulated by Hooke (1981):

$A(T)=A_{0} \exp \left(\frac{3 f}{\left[T_{\mathrm{r}}-T\right]^{k}}-\frac{Q}{R T}\right)$,

where $A_{0}=0.093 \mathrm{~Pa}^{-3} \mathrm{a}^{-1}, \quad Q / R=9.48 \times 10^{3} \mathrm{~K}, \quad f=$ $0.53 \mathrm{~K}^{k}, k=1.17$ and $T_{\mathrm{r}}=273.39 \mathrm{~K}$; in addition, a 3-D internal temperature field produced by Pattyn (2010) is used for $T$.

While the effective viscosity calculation incorporates vertically integrated stresses, the component of mass flux due to vertical shearing has to be neglected due to its effect of significantly reducing the maximum stable time step. The resulting model still outperforms the shelfy-stream approximation, however, when compared to full Stokes solutions of grounding line problems (Pattyn et al., 2013; Cornford et al., 2013). Resistance to basal sliding is governed by a linear viscous friction law, so the basal traction is

$\boldsymbol{\tau}^{b}=\left\{\begin{array}{ll}-C \boldsymbol{u} & \text { if } \frac{\rho_{\mathrm{i}}}{\rho_{\mathrm{w}}}>-b \\ 0 & \text { otherwise }\end{array}\right.$,

where $C(x, y)$ is a basal friction coefficient, $\rho_{\mathrm{w}}$ is the density of sea water and $b(x, y)$ is the bedrock elevation. An inverse problem is solved to find spatially varying fields of both $C$ and $\phi$, as discussed in Sect. 2.3.

The model uses a block-structured adaptive mesh refinement method to allow for a higher grid resolution to be applied near to the grounding line than for the rest of the ice sheet. In all of the experiments presented here, the BISICLES mesh evolves during the simulations so that the finest resolution is maintained at grounding lines where the ice velocity is greater than $100 \mathrm{~m} \mathrm{a}^{-1}$, even though the grounding line location may sweep across a significant proportion of the model domain (see inset of Fig. $2 \mathrm{~d}$ for example). The time step is chosen to satisfy the CFL (Courant-Friedrichs-Levy) condition.

\subsection{Input data and set-up}

Basal topography and initial ice thickness are taken from the Bedmap2 compilation (Fretwell et al., 2013). This includes all the data collected in the study area by Ross et al. (2012) as well as several other recent improvements to the ice thickness data coverage in the Weddell Sea area (see Fretwell et al., 2013). A correction for firn depth was applied to the ice thickness so that flotation could be calculated with a single density for ice (van den Broeke, 2008). The ice surface was then modified by means of a smoothing routine which fits a cubic spline curve to surface points at $20 \mathrm{~km}$ spacing. This was necessary, as detail in the Bedmap2 surface topography (specifically surface undulations of the order of $\sim 20 \mathrm{~m}$ vertical and $\sim 5 \mathrm{~km}$ horizontal that are present throughout the region) had the effect of disrupting the continuity of ice streams 
produced in the model. The inverse modelling approach to deriving basal boundary conditions from the ice sheet geometry, ice temperatures and satellite measurements of ice velocity (described in Sect. 2.3) is sensitive to the surface gradient of the ice sheet. A mismatch in the detail of surface and basal topographies caused the model to erroneously infer the presence of basal sticky spots, which resulted in discontinuous ice streams. After smoothing of the ice surface, the bed topography (and hence ice thickness) was adjusted with the method of Le Brocq et al. (2010) to ensure that the grounding line location was within one $1 \mathrm{~km}$ grid cell of the Antarctic Surface Accumulation and Ice Discharge (ASAID) project grounding line (Bindschadler et al., 2011).

The model domain was chosen to include the entire catchments of the Evans, Carlson, Rutford, Institute, Möller and Foundation ice streams as well as the lower parts of the Support Force and Recovery catchments (Fig. 1). For the time periods relevant to this study (up to 2000 years), we assume that the upper parts of the Support Force catchment (where velocities are $<20 \mathrm{~m} \mathrm{a}^{-1}$ ) can be considered as static ice. In the Recovery Ice Stream, however, ice flow faster than $100 \mathrm{~m} \mathrm{a}^{-1}$ extends further inland than the model domain. Its behaviour may therefore not be accurately represented in the model.

The surface mass balance field used in the model is taken from Arthern et al. (2006). Within the model domain this prescribes a roughly uniform south-north accumulation increase from $\sim 0.1$ to $\sim 0.5 \mathrm{~m} \mathrm{a}^{-1}$. No explicit calving model is used; instead, the calving front of the Filchner-Ronne Ice Shelf is fixed at the location given in the Bedmap2 data set, and all ice crossing this line is assumed to be lost to calving.

\subsection{Inverse modelling of basal parameters}

In order to reproduce the present-day ice sheet satisfactorily it is necessary to provide spatially variable fields of the rate factor $\mathrm{A}$ and of the sliding coefficient $\mathrm{C}$. Ice viscosity is dependent on Glen's rate factor A, which can be calculated as a function of ice temperature with the Hooke (1981) relation. We choose, however, to include an additional multiplier $\phi$ to represent damage to the fabric of the ice that has the effect of decreasing the effective viscosity, particularly near to shear margins. As field measurements of $C$ and $A$ (or $\phi$ ) are not available, we follow the control method approach of MacAyeal (1993) to determine their values, subject to the model equations and the present-day ice sheet geometry (Fretwell et al., 2013), temperature (Pattyn, 2010) and surface velocity (Rignot et al., 2011).

We optimise the fit between modelled ice velocities and satellite surface velocity observations (Fig. 2c) with the upper and lower ice surface topographies fixed. We use a gradient-based optimisation method (non-linear conjugate gradient method) to iteratively minimise an objective cost function quantifying the difference between observed and modelled velocities. The basic optimisation problem is un- derdetermined, because there are two unknown fields but just a single field of observations, and prone to produce large fluctuations in $C$ and $\phi$ in response to noise in the observations. Tikhonov regularization penalty functions for each of the variables are also included to enforce a solution where both $C$ and $\phi$ are smoothly varying

Ice outside the catchment of the Filchner-Ronne Ice Shelf was given zero velocity, zero surface accumulation and a very sticky bed in order to provide an unchanging boundary condition at the ice divide. As an initial guess we set $\phi$ equal to 1 everywhere and $C$ equal to $100 \mathrm{~Pa} \mathrm{~m}^{-1}$ a within ice streams, increasing as an exponential function of measured velocity where the ice-flow velocity is less than $100 \mathrm{~m} \mathrm{a}^{-1}$. The L2-norm misfit (integral of squares) was improved by a factor of 10 after 16 iterations. A further 16 iterations produces an improvement by only a factor of 1.5 . Figure 2 shows the results of the control problem after 16 iterations. The trunks of all ice streams and many of their tributaries are characterised by low values of $C$. Away from the ice shelf, values of $\phi$ less than 1 (reduced viscosity) are mainly found around shear margins, while stiffer ice is found upstream and in slower tributaries.

\subsection{Sub-shelf mass balance parametrisation}

When allowing the ice thickness to evolve using the velocity derived from the control method, the flux divergence is initially large. This is likely to be due to artefacts of interpolation and other sources of error in the ice sheet geometry. As a result, a 50-year model run was performed with the grounding line location and ice shelf thickness held constant to allow for the ice sheet surface geometry to relax. From the last time step of this run, the flux divergence within the ice shelf is retained, and from it a two-part parametrisation of the sub-ice-shelf basal mass balance is developed following the method described by Gong et al. (2014). Two spatially continuous fields are produced that each cover the entire model domain, one for application near to the grounding line $\left(M_{\mathrm{GL}}\right)$ and the other, the ambient field $\left(M_{\mathrm{A}}\right)$, relevant to floating ice away from the grounding line. $M_{\mathrm{GL}}$ and $M_{\mathrm{A}}$ are determined by considering the flux divergence in regions close to and far from the initial grounding line respectively, smoothed to remove short-wavelength features, and then extrapolated into the surrounding regions.

This extrapolation allows for the basal melt field to adapt to the change in grounding line location by effectively transferring the grounding line melt rate to the new grounding line location. The two fields are then combined using a weighting parameter to transition smoothly at each new time step (over a distance of approximately $35 \mathrm{~km}$ on the floating side of the grounding line) so that the maximum melting follows the grounding line as satellite measurements indicate (Rignot and Jacobs, 2002). At time $t=0$ years in the forward model runs, the combined subshelf mass balance field (Fig. 3a) shows a similar pattern 

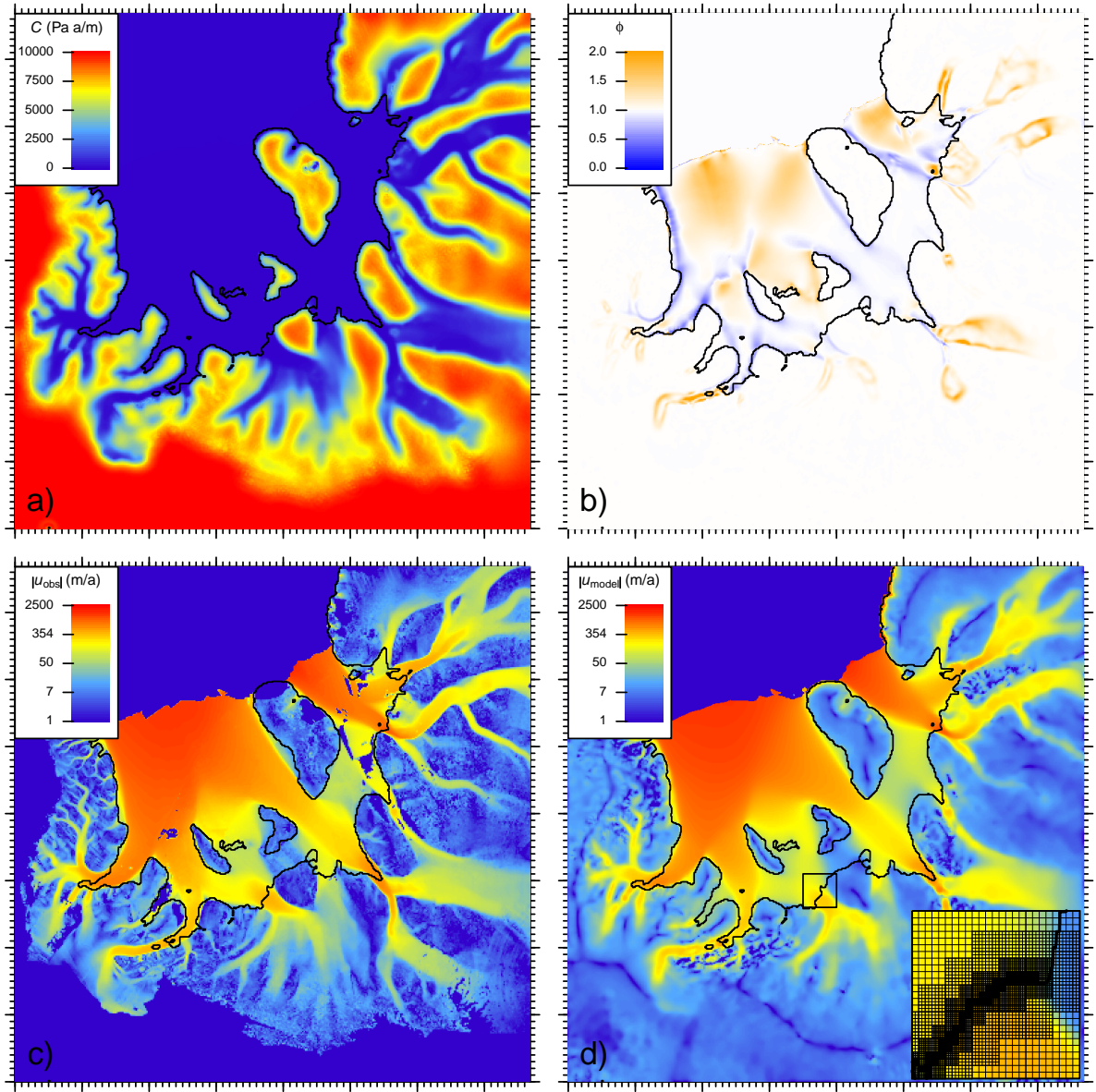

Figure 2. Results of the inverse problem after 16 iterations for (a) the basal traction parameter $C$ (red is "sticky"; blue is "slippery"), (b) the effective viscosity factor $\phi$, (c) observed surface velocity and (d) modelled velocity from the start of the reference run. In each case the initial location of the grounding line for all forward simulations is shown in black.
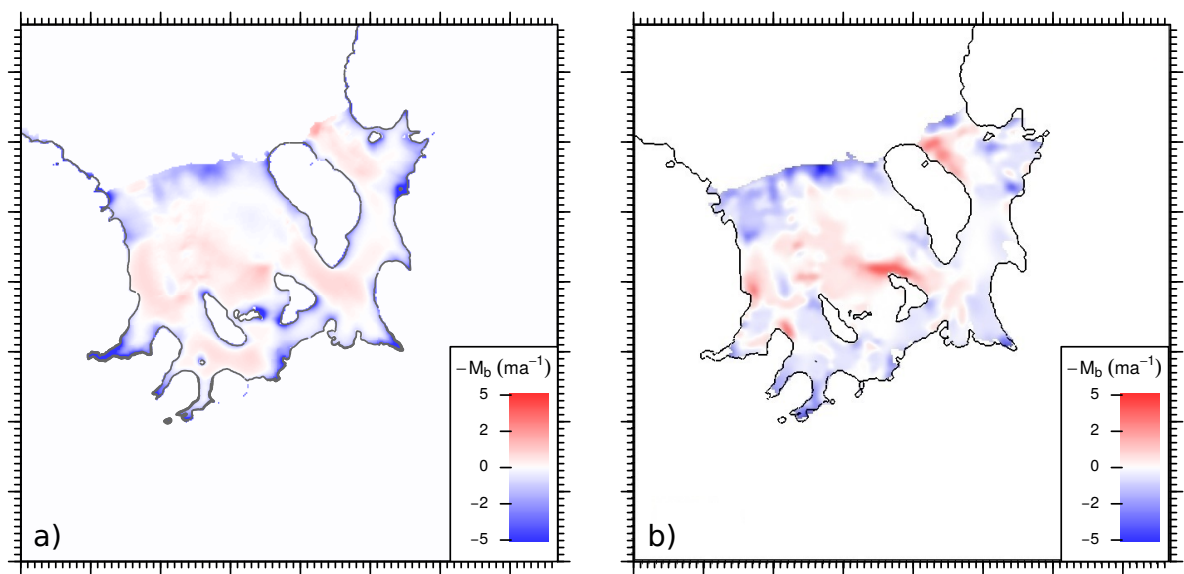

Figure 3. (a) Combined grounding line and ambient basal mass balance fields for floating ice at time $t=0$ years. (b) Basal mass balance of the Filchner-Ronne Ice Shelf calculated by Joughin and Padman (2003) from measured ice velocity, ice thickness and snow accumulation and assuming a steady state. 
to the results of Joughin and Padman (2003) (Fig. 3b), but with slightly greater melting near ice stream grounding lines and less freeze-on in the centre of the ice shelf. This basal melt rate combined with surface accumulation from Arthern et al. (2006) should result in an approximately steady-state ice sheet with a similar configuration to that of the present day. These input fields then form the basis of our reference experiment to which perturbations can be made.

\section{Forward model runs}

\subsection{Model grid refinement}

The meshes employed all have a coarsest resolution of $4 \mathrm{~km}$, but the finest resolution, imposed at the grounding line, is chosen with care. We investigated the appropriate resolution to use for the grounding line by conducting a series of experiments with increasing levels of refinement. A single level of grid refinement reduces the cell size from $\Delta x$ to $\Delta x / 2$ (where $\Delta x$ is the initial grid size before refinement) for at a distance of at least $4 \Delta x$ upstream and downstream of any grounding line within specifically defined parts of the domain. The distance $4 \Delta x$ was found to be sufficient in earlier studies (Cornford et al., 2013). Two levels of refinement adds a further eight-deep layer of cells that are half as large again to either side of the grounding line, and so on. To reduce computation time, the parts of the domain in which grid refinement may occur are limited to the current grounding line areas and potential retreat paths of the Evans, Carlson, Rutford, Institute, Möller and Foundation ice streams, as well as, within these areas, to cells where ice flow is faster than $100 \mathrm{~m} \mathrm{a}^{-1}$.

Using the surface and basal mass balance inputs described in Sect. 2, we ran forward simulations for 200 years with levels of refinement increasing from 0 (minimum cell size $=4 \mathrm{~km})$ to $5($ minimum cell size $=125 \mathrm{~m})$. Initial and final grounding line positions for each simulation are shown in Fig. 4 for each of the main ice streams in the model domain. At $t=200$ years the grounding lines of the Evans, Carlson, Rutford and Foundation ice streams have all advanced by between 40 and $100 \mathrm{~km}$ to reach the widening of their fjords where they meet the bay containing the bulk of the Filchner-Ronne Ice Shelf. The Institute Ice Stream has advanced by between 5 and $20 \mathrm{~km}$ out into an unconstrained region of the Filchner-Ronne Bay, while the grounding line of the Möller Ice Stream has remained stationary. The difference in the resulting grounding line position with further refinement decreases as the resolution improves. As the time taken to perform a simulation increases exponentially with the number of levels of refinement, it is necessary to select an optimum compromise.

Previous modelling studies have found that, where the transfer to frictionless sliding is gradual, a grid size of less than $1 \mathrm{~km}$ is necessary in order to model movement of the grounding line accurately (e.g. Vieli and Payne, 2005; Pattyn et al., 2006; Durand et al., 2009; Gladstone et al., 2010). In the MISMIP3D intercomparison project (Pattyn et al., 2013), a BISICLES simulation with a maximum resolution of $400 \mathrm{~m}$ was found to have a similar grounding line sensitivity and response time to a high-resolution full Stokes solution (although this was for the more difficult test of a sharp grounding line transition). That result was corroborated by tests of the BISICLES model on Pine Island Glacier in the Amundsen Sea, where a first-order rate of convergence of grounding line position was found for simulations with a finest cell resolution $\leq 500 \mathrm{~m}$ (Cornford et al., 2013).

Taking into account the results of this previous work, we chose to use three levels of refinement above the base $4 \mathrm{~km}$ mesh, giving a maximum resolution at the grounding line of 500 m. Our results in Fig. 4 show that further refinement continues to increase the sensitivity of the grounding line location, but only by small and decreasing amounts which come at significant cost in terms of the simulation runtime.

\subsection{The reference experiment}

In order to investigate the long-term stability of the Filchner-Ronne tributary ice streams, the reference experiment, with three levels of refinement, was run forward for a total of 2000 years. Figure 5 provides a summary of this experiment. Figure 5a shows the total net change in ice thickness and grounding line location over 2000 years of constant conditions and Fig. $5 \mathrm{~b}$ shows the time series of cumulative volume-above-flotation change, broken down by drainage basin catchment for the main ice streams.

Significant variations in the behaviour of the ice streams become evident during the course of this experiment. In the case of the Evans, Carlson, Rutford and Foundation ice streams, relatively little change occurs between $t=200$ and $t=2000$ years. The grounding lines advance slightly and stabilise, while the inland parts of the catchments and the newly grounded areas thicken. The Institute Ice Stream loses volume above flotation continuously from around $t=200$ years onward, reaching a rate of $\sim 4 \mathrm{~km}^{3} \mathrm{a}^{-1}$ by $t=500$ years and accelerating to $\sim 8 \mathrm{~km}^{3} \mathrm{a}^{-1}$ by the end of the run. This behaviour suggests that it is not in equilibrium with the forcing fields. The Möller Ice Stream loses volume above flotation at a steady rate of $\sim 1-2 \mathrm{~km}^{3} \mathrm{a}^{-1}$. By $t=2000$ years, the grounding lines of the both the Institute and Möller ice streams have retreated by up to $100 \mathrm{~km}$.

Our reference run is intended merely as an approximation. It represents the conditions necessary to maintain a stable ice sheet with a configuration as close to that of the present day as possible. In common with other ice sheet modelling studies (e.g. Seroussi et al., 2011; Larour et al., 2012) we find that, even after control method matching of the ice surface velocity to InSAR measurements, the model is unable to match the observed ice fluxes at those ice streams which flow through well-defined narrow channels (Fig. 2c and d). Over 

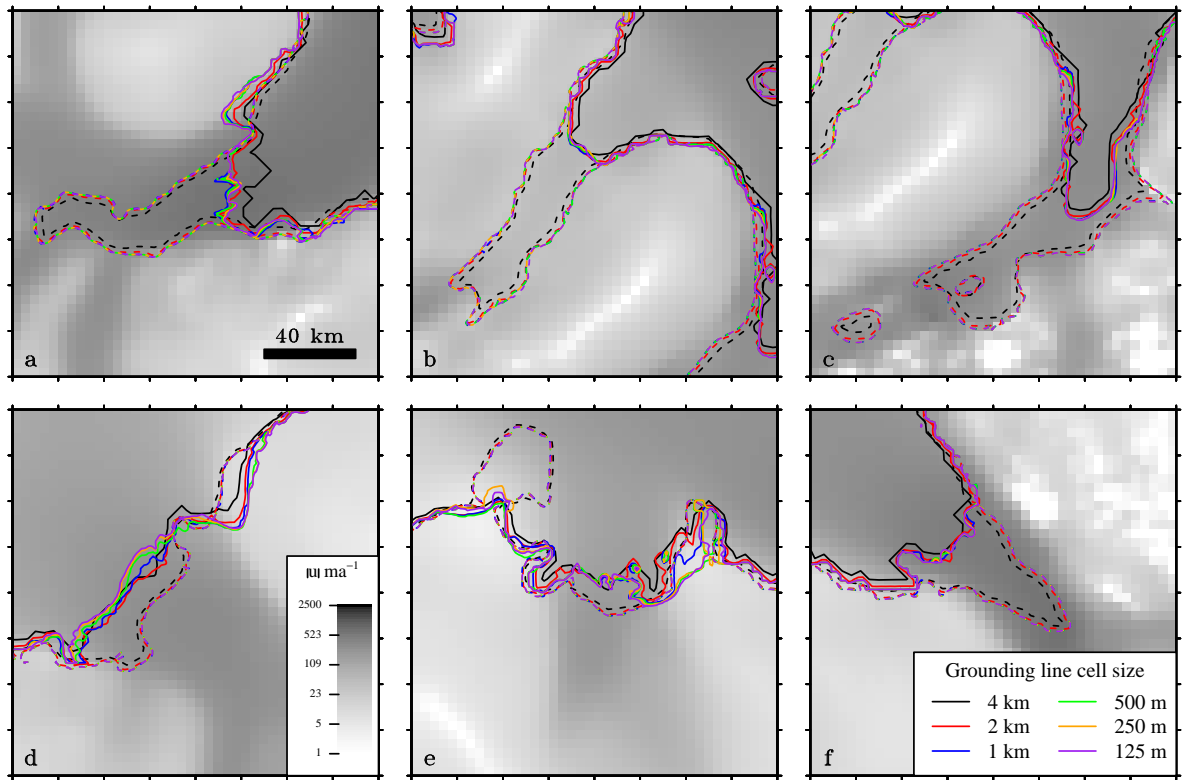

Figure 4. Results of the 200-year grounding line convergence experiment with increasing levels of grounding line resolution for the major ice streams within the model domain. Grounding line locations are colour-coded to indicate the degree of grounding line refinement; initial positions ( $t=0$ years) are shown as dashed lines and final positions as solid lines. (a) Evans Ice Stream, (b) Carlson Inlet, (c) Rutford Ice Stream, (d) Institute Ice Stream, (e) Möller Ice Stream and (f) Foundation Ice Stream.
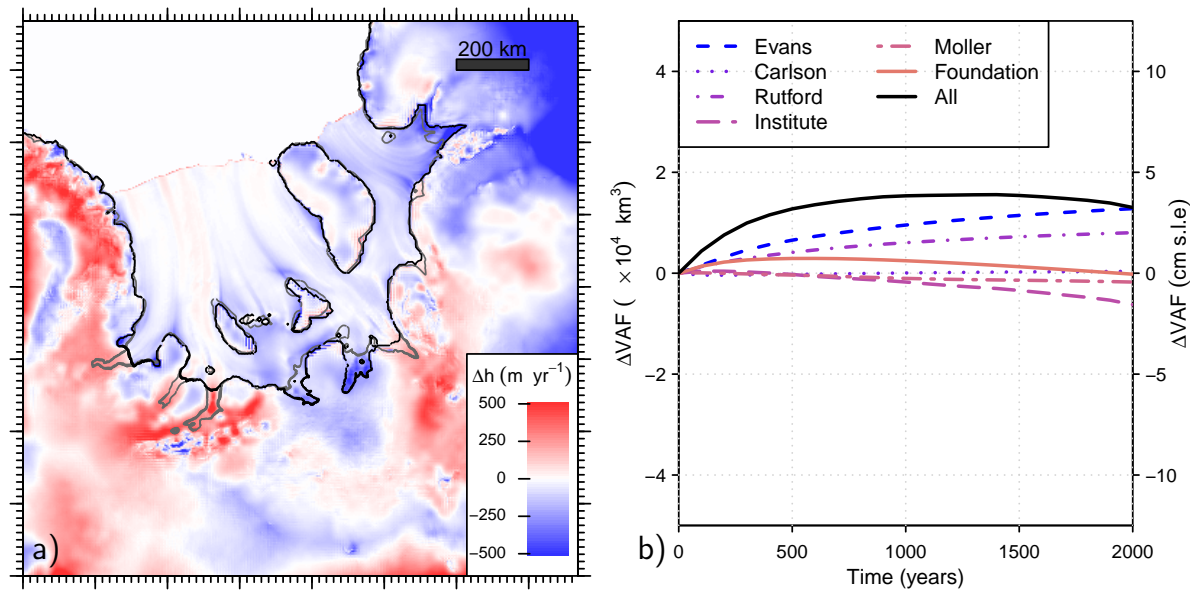

Figure 5. (a) Map showing total change in ice thickness (colour scale) and grounding line position over a 2000-year model run (grounding line in grey, $t=0$ years; black, $t=2000$ years). (b) Plot of volume above flotation change $\left(\mathrm{km}^{3}\right)$ against time for each of the ice stream catchments. The solid black line is the cumulative combined volume change for all six ice streams.

the length of the control run, the result is that thickening occurs near to the grounding lines of the Rutford, Evans, Carlson Inlet and Foundation ice streams in particular (Fig. 5a). The difficulty in maintaining a steady state is due to the high amplitude and frequency variations that are required in the sub-ice-shelf basal mass balance to balance the flux divergence. The flux divergence field produced by the controlproblem-derived ice velocity and geometry observations is noisy due to artefacts of interpolation and other sources of error in the ice sheet geometry. The high amplitude and fre- quency variations in the sub-ice-shelf basal mass balance field are unrealistic and hence need to be smoothed out, leading to the ice sheet not maintaining a steady state. This problem inhibits our ability to make predictions and means that the results of the reference experiment cannot be viewed as a future prediction for a scenario of constant climate. The reference run should therefore be viewed solely as a neutral starting point from which to assess the relative sensitivity of the ice streams to change, and not as a prediction. 

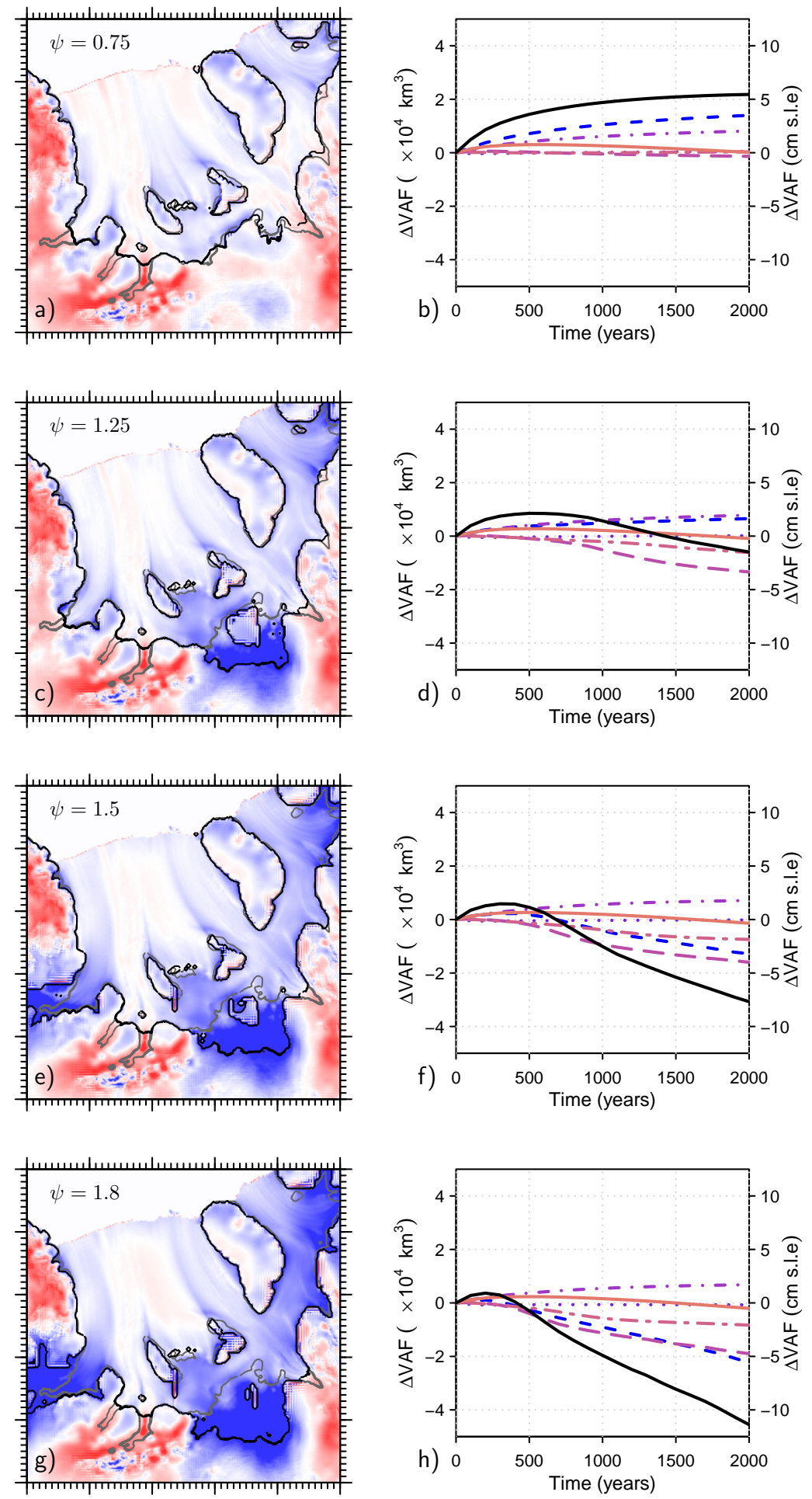

Figure 6. Left-hand side (a, c, e, g) panels are plan-view maps showing changes in ice thickness (colour scale) and grounding line position (grey: start; black: end) over 2000-year model runs. Right-hand side (b, d, f, h) panels are plots of cumulative volume above flotation change against time for each of the ice stream catchments for the same experiment. In each experiment the sub-shelf accumulation/melt-rate field has been multiplied by a factor $\psi$ : (a and $\mathbf{b}) \psi=0.75$, (c and $\mathbf{d}) \psi=1.25$, (e and $\mathbf{f}) \psi=1.5$, and $(\mathbf{g}$ and $\mathbf{h}) \psi=1.8$. The colour scale for the volume changes in (a), (c), (e) and (g) is the same as for Fig. 5a, and the code for plot lines in (b), (d), (f) and (h) is given in Fig. 5b. 


\subsection{Perturbations to sub-shelf melting}

In order to investigate the sensitivity of the various ice streams to changes in sub-ice-shelf mass balance, we chose to apply a linear multiplier $\psi$ to the basal accumulation/ablation field for floating ice (shown in Fig. 3a). Using a positive linear multiplier $(\psi>1.0)$ has the effect of increasing the magnitude of both net ablation in melting areas and net accumulation in areas where there is freeze-on, while a multiplier $0<\psi<1.0$ will have the opposite effect. We prefer this approach to a uniform shift (addition or subtraction) from the basal mass balance field as it is likely to be more realistic. The resulting changes should in fact be crudely analogous to an increase or decrease in the rate of thermohaline convection beneath the ice shelf where more energetic circulation within the cavity increases the rate of seaward mass transfer, and vice versa (Jacobs et al., 1992).

Aside from the application of a multiplying factor to the basal mass balance for floating ice, all other conditions were identical to the reference experiment described in the previous section. Figure 6 shows equivalent results to those for the reference experiment given in Fig. 5 for four experiments with different sub-shelf mass balance factors. In Fig. 6a and b a near-steady-state ice sheet is obtained after 2000 years with $\psi=0.75$. Although significant ice thickness increase occurs in the Evans and Rutford ice streams, grounding lines do not advance substantially further than in the reference experiment. Similarly stable ice sheet configurations with moderate increases in ice thickness and minor grounding line movements can be obtained using $0.5<\psi<0.9$.

Figure $6 \mathrm{c}-\mathrm{h}$ show results of incremental changes to $\psi$. Even small increases cause a corresponding acceleration of retreat for both the Institute and Möller ice streams. Once retreat has begun in this sector it continues unabated throughout all of our model runs. The rate of basal melting at the grounding line can therefore be shown to affect the rate of retreat only and not the ultimate position at which the ice sheet re-stabilises. In contrast to this, the Rutford Ice Stream and Carlson Inlet Glacier are particularly insensitive in our experiments, remaining fixed at their advanced grounding line positions even under quite substantial increases in the melt rates at their fronts.

If the Institute and Möller ice streams seem to be intrinsically unstable for $\psi>1.0$, and the Rutford and Carlson ice streams are unaffected by increases in basal melt rates at their grounding lines, then the Evans Ice Stream demonstrates a threshold behaviour (Fig. 7). Initially showing very little sensitivity to sub-shelf melt rate, the ice stream retains an advanced grounding line up to a value of $\psi=1.25$ (equivalent to a melt rate near its grounding line of $8 \mathrm{~m} \mathrm{a}^{-1}$ ). At this point a threshold appears to be reached and any further increase in melting results in a rapid and catastrophic collapse (Fig. 6g and h).

\subsection{Perturbations to surface mass balance}

Very little surface melting occurs on the major Antarctic ice sheets even at sea level. Consequently the surface mass balance is uniformly positive (excluding some blue-ice areas in East Antarctica) and, at least at the model scale, smoothly varying (Arthern et al., 2006). To investigate the sensitivity of the Filchner-Ronne ice streams to changes in surface accumulation, we therefore found it most convenient to apply a uniform shift $(\omega)$ to the base level used in the reference experiment.

As described in Sect. 2.2, the surface mass balance for the reference experiment increases from $\sim 0.10$ to $\sim 0.50 \mathrm{~m} \mathrm{a}^{-1}$ in a roughly south-north direction. Ligtenberg et al. (2013) and Agosta et al. (2013) describe predictions for future accumulation increases up to the year 2200 that, when averaged over the entire Antarctic Ice Sheet (including ice shelves), are equivalent to $\sim 0.01 \mathrm{~m}$ w.e. for the (IPCC) E1 scenario, and $\sim 0.04 \mathrm{~m}$ w.e. for the A1B scenario. We use these results as a guide to realistic values of $\omega$ so that we can investigate the sensitivity of our model accordingly.

A positive shift in surface accumulation accompanied by no change in sub-shelf melting has the predictable effect of increasing the ice thickness in those ice streams that were stable at their advanced grounding line locations under the reference scenario. An increase in surface accumulation by only a small amount is sufficient to stabilise the Institute Ice Stream, while the Möller Ice Stream does not fully stabilise at its current grounding line location unless surface accumulation is increased by at least $0.05 \mathrm{~m}$ w.e. $\mathrm{a}^{-1}$.

At $\psi=1.5$ and with present-day accumulation $(\omega=$ $0.0 \mathrm{~m}$ w.e. $\mathrm{a}^{-1}$ ) there is very substantial and relatively rapid retreat in the Weddell Sea sector (Fig. 6 e and f). An increase of $0.01 \mathrm{~m}$ w.e. $\mathrm{a}^{-1}$ in surface accumulation has a fairly minimal impact on this result (Fig. 8a and b). Increasing the accumulation shift to $\omega=0.025 \mathrm{~m}$ w.e. $\mathrm{a}^{-1}$ (Fig. $8 \mathrm{c}$ and d) or $0.05 \mathrm{~m}$ w.e. $\mathrm{a}^{-1}$ (Fig. $8 \mathrm{e}$ and $\mathrm{f}$ ) does have a progressively stronger effect towards reducing the amount of retreat of the Institute and Möller ice streams within the model time frame, but is not sufficient to fully mitigate the effects of the increase in grounding line melt. Figure $8 \mathrm{f}$ demonstrates an interesting situation where the Weddell Sea sector of the ice sheet, taken as a whole, experiences significant growth over the modelled period (due to the increased accumulation) while both the Institute and Möller ice streams are in continuous retreat. Thus we find a situation where particular basins, due to their geometrical configuration, can experience an unstable retreat even when they form part of a growing ice sheet.

\subsection{Grounding line melting vs. "ambient" shelf melting}

With our parametrisation of sub-shelf mass balance (described in Sect. 2.4) it is straightforward to apply different multiplying factors to the area near the grounding line $\left(\psi_{\mathrm{gl}}\right)$ and to the area away from the grounding line, or ambient 

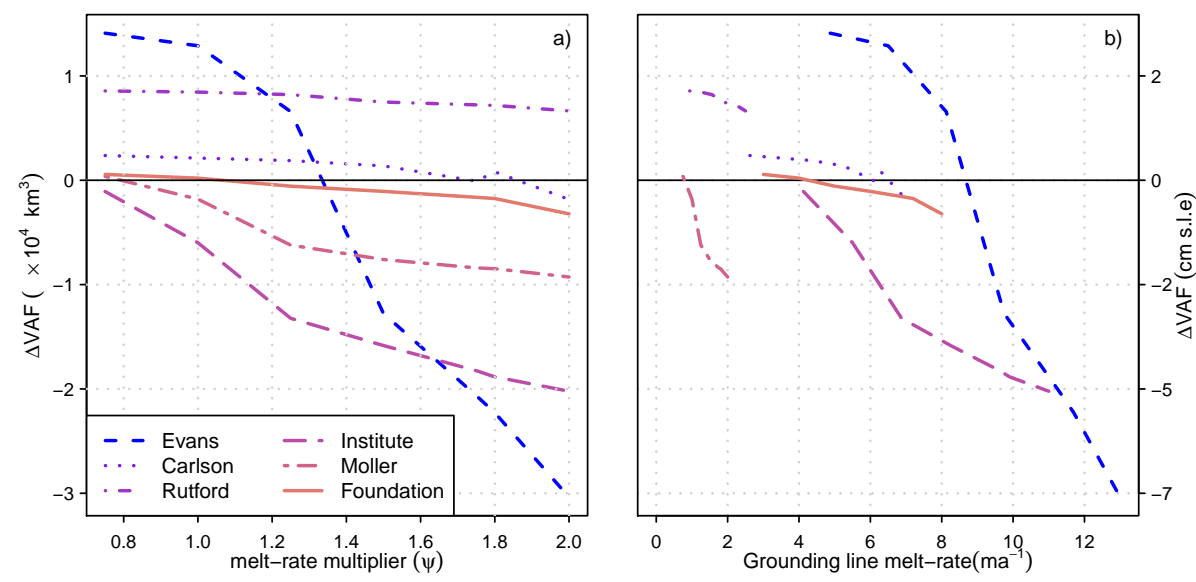

Figure 7. Total volume above flotation change by ice stream catchment over the 2000-year model runs as a function of (a) $\psi$ and (b) the melt rate at the ice stream grounding line at $t=0$ years.

region $\left(\psi_{\mathrm{am}}\right)$. This is of interest because it allows us to investigate the relative importance of direct melting of the ice streams at/near their grounding lines vs. more general thinning of the shelf and consequent loss of buttressing and back pressure on ice stream flow.

Figure 9 demonstrates that a multiplying factor has minimal impact when applied to the ambient part of the sub-shelf mass balance only, and that the ice stream responses noted in the earlier parts of this paper are due to increases in melting in the vicinity of the grounding line. There are two reasons why this should be the case: (1) much of the "ambient" part of the ice shelf has a positive or near-zero mass balance in the reference field, and (2) melt in the region of the islands within the ice shelf, which may be important for buttressing (such as the Korff and Henry ice rises and the Doake Ice Rumples; see Fig. 1), is subject to the grounding line multiplier, rather than the ambient factor. In order to effectively investigate the impact of an increase in sub-shelf melting away from ice stream grounding lines, a change to the approach was required.

Firstly, all grounded parts of the Filchner-Ronne Ice Shelf were manually identified in the model domain and the grounding lines associated with the ice rises removed from the calculation of the sub-shelf mass balance. In the new subshelf melt field the "grounding line" element is only applied near to the grounding line of the main ice sheet and not to the ice rises.

The result of a 2000-year experiment run with this new sub-shelf melt field is that the Institute Ice Stream advances out into the bay to connect with the Korff, Henry and Doake grounded areas. This occurs because the sub-shelf mass balance in the vicinity of the ice rises is now overly positive, causing their grounded areas to increase and aiding the advance of the Institute Ice Stream. The Möller Ice Stream also advances slightly, while the behaviour of the other ice streams is largely unchanged from the reference run (Fig. 10a and $b)$. The next step was to apply a uniform $\operatorname{shift}\left(\chi_{\mathrm{am}}\right)$ to the ambient component of the sub-shelf mass balance in order to investigate the effect on the various ice streams of removing the buttressing due to the grounded ice rises. A shift of $\chi_{\mathrm{am}}=-0.5 \mathrm{~m}$ w.e. significantly restrains the advance of the Institute Ice Stream and results in the model reaching an approximate equilibrium (Fig. 10e and f). A larger increase in melting (e.g. $\chi_{\mathrm{am}}=-0.75 \mathrm{~m}$ w.e.) is necessary to unground the Doake and Henry ice rises, which then rapidly leads to a substantial grounding line retreat in the Institute and Möller sector (Fig. $10 \mathrm{~g}$ and $\mathrm{h}$ ). These experiments have a component of direct melting at the grounding lines of the ice streams that is identical to the reference run; hence we can attribute the respective changes observed in the model to the "far-field" effects of melt rates in the central ice shelf and particularly around the ice rises.

\section{Discussion}

The results of the first part of this paper, where changes to the magnitude but not the pattern of sub-shelf mass balance were investigated, are summarised in Fig. 7. From this it is clear that the ice streams discharging into the Filchner-Ronne Ice Shelf can be divided into three groups: (1) those that respond very slowly and require large changes to the forcing fields to produce any retreat; (2) those quick to respond to changes in melt at their grounding lines; and (3) those which respond very quickly to a melt increase, but only after a threshold has been passed.

In the first group are the Rutford Ice Stream, Carlson Inlet and Foundation Ice Stream. The Rutford, Carlson, Foundation and also Evans ice streams exhibit the common behaviour that their grounding lines all advance to the end of their respective fjords during the early part of all forward model runs. In the case of the Carlson, Foundation and Evans ice streams, the water-column depth within the floating portions of the fjords which become grounded is very low 

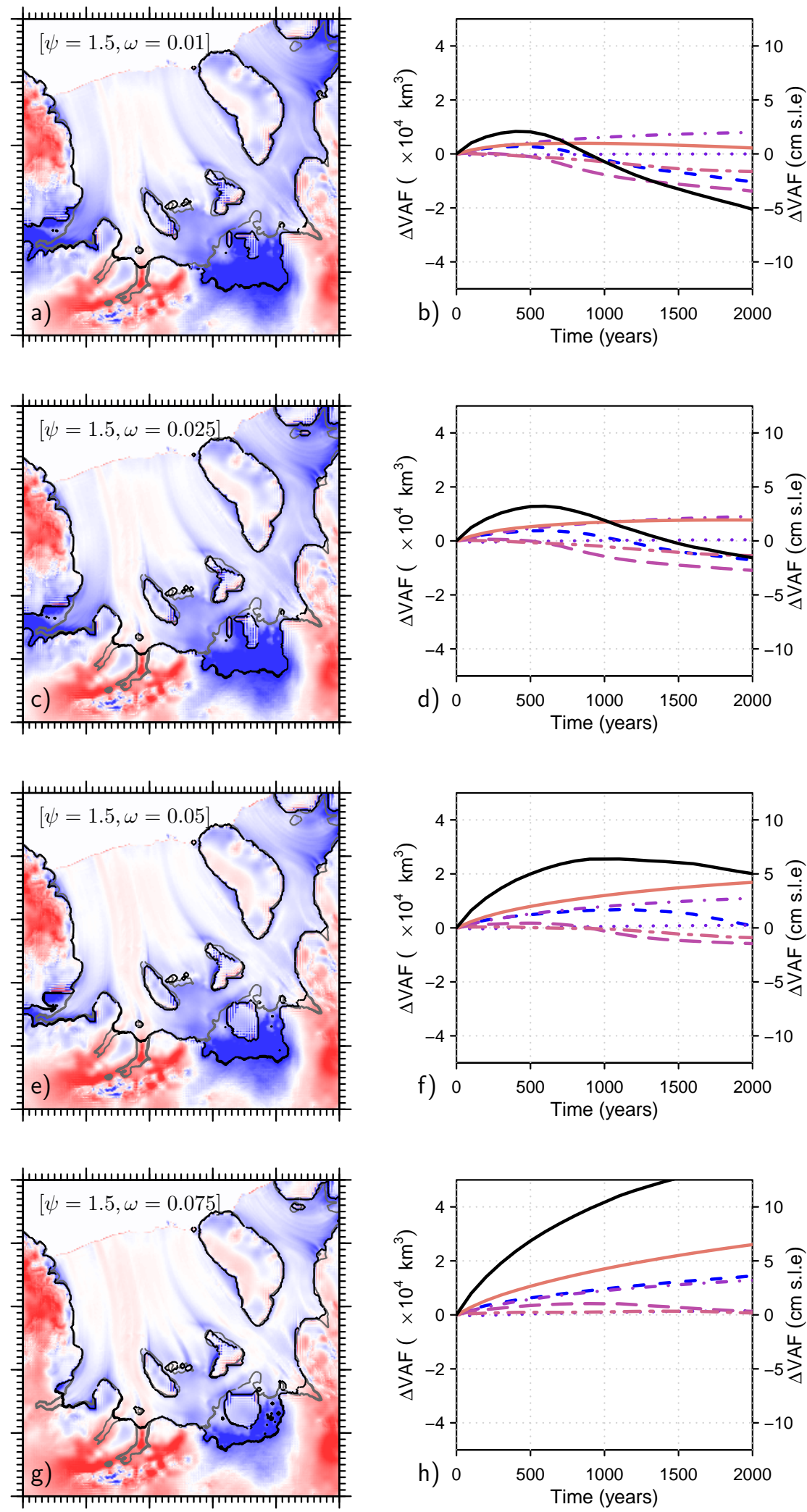

Figure 8. Ice thickness changes and grounding line locations along with time series plots of cumulative volume above flotation change by basin. In all plots the basal mass balance multiplier $\psi=1.5$, but $\omega$ varies: (a and b) $\omega=0.01 \mathrm{~m}$ w.e.; (c and $\mathbf{d}) \omega=0.025 \mathrm{~m}$ w.e.; (e and f) $\omega=0.05 \mathrm{~m}$ w.e and $(\mathbf{g}$ and $\mathbf{h}) \omega=0.075 \mathrm{~m}$ w.e. 

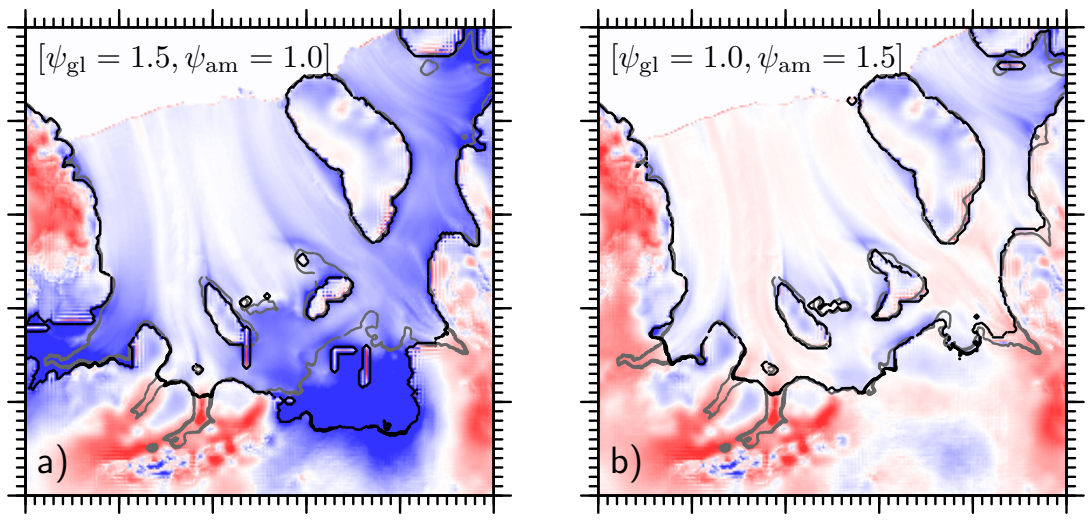

Figure 9. Grounding line location and ice thickness change over 2000-year model runs with enhanced sub-shelf accumulation/melt only (a) near to the grounding line and (b) away from the grounding line.

$(<50 \mathrm{~m}$ throughout, and in many places $<10 \mathrm{~m})$. As a result they ground very easily in the model and, once grounded on bed topographic high points near to their trough mouths, they are very stable in the model. Rutford Ice Stream is the exception in this instance as the water column below the floating ice in its fjord is around $500 \mathrm{~m}$ deep (Johnson and Smith, 1997; Fretwell et al., 2013). The Rutford Fjord, however, is the longest, narrowest and deepest of all the Filchner-Ronne tributaries and the glacier is well constrained within steep rock walls on both margins. The buttressing this provides may explain its apparent stability in the model despite the reverse bed slope throughout much of its length.

The Institute and Möller ice streams comprise the second group, the configurations of which appear to place them currently near to a critical threshold between advance and unstable retreat. A small increase in their relatively modest grounding line melt rates (e.g. $\psi \geq 1.0$; Fig. 7), or the partial removal of buttressing due to flotation of the Filchner-Ronne ice rises (Fig. 10g and $\mathrm{h}$ ), is sufficient to initiate retreat of the grounding line in the model. Once this has begun, neither ice stream finds a new equilibrium grounding line position within the period of our model runs, irrespective of the size of the perturbation. A marked difference between the Institute and Möller ice streams and the other, more stable tributaries of the Filchner-Ronne Ice Shelf is their absence of a constraining fjord. The horizontal boundaries between the Institute and Möller ice streams and slow-flowing ice are grounded well below sea level rather than on substantial bedrock topography (e.g. the Bungenstock Ice Rise). The consequent lack of buttressing due to lateral drag at their margins may explain their sensitivity to changing conditions at the base of the ice shelf.

The Evans Ice Stream has one of the smaller catchments of the Filchner-Ronne tributaries but, due to its higher rate of surface accumulation, discharges the largest volume of ice ( $\sim 36 \mathrm{Gt} \mathrm{yr}^{-1}$; Joughin and Bamber, 2005). It is unique in our model domain for its rapid response to increases in basal melting that occurs only once a melt-rate threshold has been passed (Fig. 7). The Evans Ice Stream does flow within a fjord, and has a particularly well defined set of tributaries (Rignot et al., 2011). At the mouth of its trough, however, the ice stream is better constrained on its true right bank (by the Haag Nunataks) than by the subdued topography on the Antarctic Peninsula side (Fig. 1), and this may go some way to explaining its behaviour midway between stability and sensitivity.

All of the ice streams discussed in this paper have a reverse bed slope with an average gradient of 0.004-0.009 sloping inland for a distance of 100-200 km from the grounding line and without topographic highs to provide potential pinning points. The differences in their response to either an increase in melt at their grounding lines or to a reduction in buttressing due to ice rises is therefore unlikely to be explained by variations in basal topography within the trough. Trough width has previously been shown to have a close link to ice stream stability. Even under conditions of a continuous reverse bed slope a narrowing of the available width for the ice stream can, through increase in lateral drag, have a stabilising effect during retreat (Jamieson et al., 2012).

Our results also suggest that a substantial increase in surface accumulation would be necessary to counteract a moderate increase in grounding line melt rate. This is especially so because the impact of increasing surface accumulation in our sensitivity experiments is fairly uniform, whereas the impact of sub-shelf melt increases is unevenly distributed, due to the differing responses of the ice streams as described above (Fig. 8).

\section{Conclusions}

We applied the BISICLES ice sheet model to the catchments of the ice streams feeding the Filchner-Ronne Ice Shelf in West Antarctica. We used the most up-to-date measurements of ice thickness, flow velocity, temperatures and accumula- 

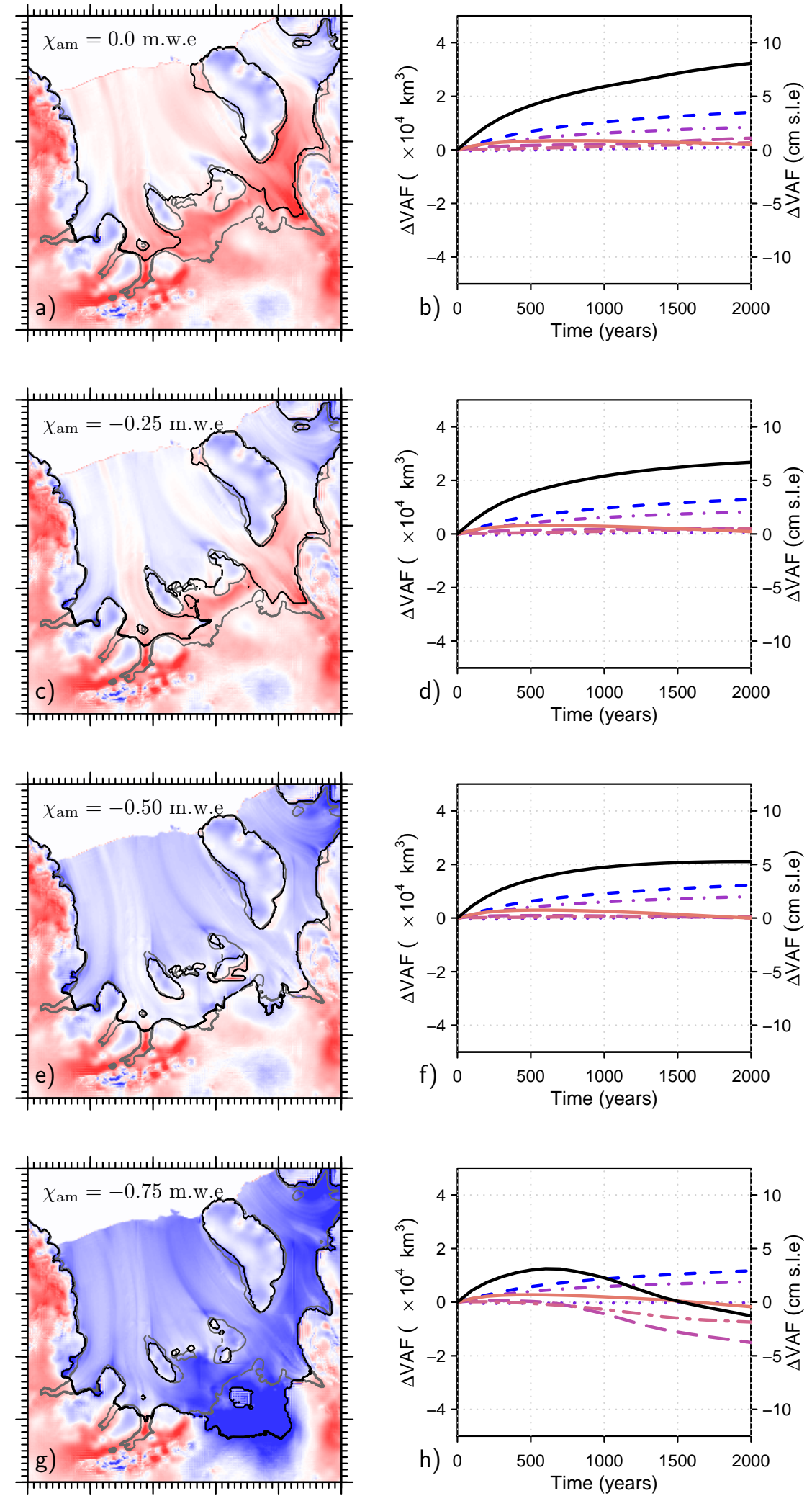

Figure 10. Results of modelling experiments where the grounding lines of ice rises within the Filchner-Ronne Ice Shelf have been isolated and the ambient melt field applied. The ambient field has then been shifted by (a and b) $0.0 \mathrm{~m}$ w.e., (c and d) $-0.25 \mathrm{mw}$ w.e, (e and f) $-0.50 \mathrm{~m}$ w.e. and ( $\mathbf{g}$ and $\mathbf{h})-0.50 \mathrm{~m}$ w.e. in order to test the effect on the ice streams of the removal of the buttressing these ice rises provide to the ice shelf. 
tion rates to produce surface and sub-ice-shelf mass balance fields which maintain, as closely as possible, a steady state when applied to the present-day Antarctic Ice Sheet configuration. Perturbations to these reference-run forcing fields were then made in order to assess the relative sensitivities of the different ice streams to changes in sub-shelf melt near the grounding lines, basal mass balance on the shelf away from the grounding lines and surface accumulation.

Model results suggest that the Institute and Möller ice streams are currently situated very close to a threshold critical for rapid retreat. In our study area they are uniquely sensitive to both increased melting at their respective grounding lines and to elevated melting in the region of the ice rises in the Filchner-Ronne Ice Shelf. Once retreat begins for these ice streams, the model fails to find a new equilibrium position for the grounding line and the ice streams continue to lose mass throughout the 2000-year period of the model runs.

In contrast, the Rutford, Carlson and Foundation ice streams appear to be quite resistant to either retreat or significant advance even with fairly substantial perturbations to the surface and sub-shelf mass balances. The Evans Ice Stream is unique in this sector in that unstable retreat will occur only after a threshold grounding line melt rate has been passed. Model results indicate that this threshold is quite high, likely requiring a $50 \%$ increase in the present-day grounding line melt rate to initiate retreat.

The different responses of the various ice streams cannot be explained entirely by features of the basal topography within their troughs. Fjord width and the effect of buttressing at lateral margins and at ice rises also affect the responses of ice streams to external forcing. In order to further improve our understanding of the behaviour of major ice streams feeding into the Filchner-Ronne Ice Shelf (outside of the Institute and Möller ice streams), further geophysical observations are required to properly characterise the nature of the topography near the grounding lines.

These factors should also be taken into account when assessing the relative vulnerability of other Antarctic ice streams to climate-change-induced retreat. For example, the Siple Coast ice streams feeding into the Ross Ice Shelf are not constrained by fjord topography, so they may act in a similar way to the Institute and Möller ice streams. However, as many factors are involved in controlling ice stream response, such as the slope of the bed topography and the presence of ice rises in the ice shelves, numerical modelling of the sort demonstrated in this paper is required.

Acknowledgements. Funding for this work was provided by UK NERC AFI grant NE/G013071/1. BISICLES development is led by D. F. Martin at Lawrence Berkeley National Laboratory, California, USA, and S. L. Cornford at the University of Bristol, UK, with financial support provided by the US Department of Energy and the UK Natural Environment Research Council.

Edited by: E. Larour

\section{References}

Agosta, C., Favier, V., Krinner, G., Gallée, H., Fettweis, X., and Genthon, C.: High-resolution modelling of the Antarctic surface mass balance, application for the twentieth, twenty first and twenty second centuries, Clim. Dynam., 41, 3247-3260, doi:10.1007/s00382-013-1903-9, 2013.

Arthern, R. J., Winebrenner, D. P., and Vaughan, D. G.: Antarctic snow accumulation mapped using polarization of $4.3 \mathrm{~cm}$ wavelength microwave emission, J. Geophys. Res., 111, D06107, doi:10.1029/2004JD005667, 2006.

Bindschadler, R., Choi, H., Wichlacz, A., Bingham, R., Bohlander, J., Brunt, K., Corr, H., Drews, R., Fricker, H., Hall, M., Hindmarsh, R., Kohler, J., Padman, L., Rack, W., Rotschky, G., Urbini, S., Vornberger, P., and Young, N.: Getting around Antarctica: new high-resolution mappings of the grounded and freely-floating boundaries of the Antarctic ice sheet created for the International Polar Year, The Cryosphere, 5, 569-588, doi:10.5194/tc-5-569-2011, 2011.

Brunt, K. M., Fricker, H. A., and Padman, L.: Analysis of ice plains of the Filchner-Ronne Ice Shelf, Antarctica, using ICESat laser altimetry, J. Glaciol., 57, 965-975, doi:10.3189/002214311798043753, 2011.

Cornford, S. L., Martin, D. F., Graves, D. T., Ranken, D. F., Le Brocq, A. M., Gladstone, R. M., Payne, A. J., Ng, E. G., and Lipscomb, W. H.: Adaptive mesh, finite volume modeling of marine ice sheets, J. Comput. Phys., 232, 529-549, doi:10.1016/j.jcp.2012.08.037, 2013.

Dupont, T. K. and Alley, R. B.: Assessment of the importance of ice-shelf buttressing to ice-sheet flow, Geophys. Res. Lett., 32, L04503, doi:10.1029/2004GL022024, 2005.

Durand, G., Gagliardini, O., Zwinger, T., Le Meur, E., and Hindmarsh, R. C.: Full Stokes modeling of marine ice sheets: influence of the grid size, Ann. Glaciol., 50, 109-114, doi:10.3189/172756409789624283, 2009.

Fretwell, P., Pritchard, H. D., Vaughan, D. G., Bamber, J. L., Barrand, N. E., Bell, R., Bianchi, C., Bingham, R. G., Blankenship, D. D., Casassa, G., Catania, G., Callens, D., Conway, H., Cook, A. J., Corr, H. F. J., Damaske, D., Damm, V., Ferraccioli, F., Forsberg, R., Fujita, S., Gim, Y., Gogineni, P., Griggs, J. A., Hindmarsh, R. C. A., Holmlund, P., Holt, J. W., Jacobel, R. W., Jenkins, A., Jokat, W., Jordan, T., King, E. C., Kohler, J., Krabill, W., Riger-Kusk, M., Langley, K. A., Leitchenkov, G., Leuschen, C., Luyendyk, B. P., Matsuoka, K., Mouginot, J., Nitsche, F. O., Nogi, Y., Nost, O. A., Popov, S. V., Rignot, E., Rippin, D. M., Rivera, A., Roberts, J., Ross, N., Siegert, M. J., Smith, A. M., Steinhage, D., Studinger, M., Sun, B., Tinto, B. K., Welch, B. C., Wilson, D., Young, D. A., Xiangbin, C., and Zirizzotti, A.: Bedmap2: improved ice bed, surface and thickness datasets for Antarctica, The Cryosphere, 7, 375-393, doi:10.5194/tc-7-3752013, 2013.

Gladstone, R. M., Lee, V., Vieli, A., and Payne, A. J.: Grounding line migration in an adaptive mesh ice sheet model, J. Geophys. Res., 115, F04014, doi:10.1029/2009JF001615, 2010.

Goldberg, D., Holland, D. M., and Schoof, C.: Grounding line movement and ice shelf buttressing in marine ice sheets, J. Geophys. Res., 114, F04026, doi:10.1029/2008JF001227, 2009.

Gong, Y., Cornford, S. L., and Payne, A. J.: Modelling the response of the Lambert Glacier-Amery Ice Shelf system, East Antarctica, 
to uncertain climate forcing over the 21 st and 22 nd centuries, The Cryosphere, 8, 1057-1068, doi:10.5194/tc-8-1057-2014, 2014.

Gudmundsson, G. H.: Ice-shelf buttressing and the stability of marine ice sheets, The Cryosphere, 7, 647-655, doi:10.5194/tc-7647-2013, 2013.

Gudmundsson, G. H., Krug, J., Durand, G., Favier, L., and Gagliardini, O.: The stability of grounding lines on retrograde slopes, The Cryosphere, 6, 1497-1505, doi:10.5194/tc-6-1497-2012, 2012.

Hellmer, H. H., Kauker, F., Timmermann, R., Determann, J., and Rae, J.: Twenty-first-century warming of a large Antarctic ice-shelf cavity by a redirected coastal current, Nature, 485, 225-228, doi:10.1038/nature11064, 2012.

Hooke, R. L.: Flow law for polycrystalline ice in glaciers: Comparison of theoretical predictions, laboratory data, and field measurements, Rev. Geophys., 19, 664-672, doi:10.1029/RG019i004p00664, 1981.

Jacobs, S. S., Hellmer, H., Doake, C. S. M., Jenkins, A., and Frölich, R.: Melting of ice shelves and the mass balance of Antarctica, J. Glaciol., 38, 375-387, 1992.

Jacobs, S. S., Hellmer, H. H., and Jenkins, A.: Antarctic Ice Sheet melting in the southeast Pacific, Geophys. Res. Lett., 23, 957-960, doi:10.1029/96GL00723, 1996.

Jamieson, S. S. R., Vieli, A., Livingstone, S. J., O'Cofaigh, C., Stokes, C., Hillenbrand, C.-D., and Dowdeswell, J. A.: Icestream stability on a reverse bed slope, Nat. Geosci., 5, 799-802, doi:10.1038/ngeo1600, 2012.

Jenkins, A., Corr, H. F., Nicholls, K. W., Stewart, C. L., and Doake, C. S. M.: Interactions between ice and ocean observed with phase-sensitive radar near an Antarctic ice-shelf grounding line, J. Glaciol., 52, 325-346, doi:10.3189/172756506781828502, 2006.

Johnson, M. and Smith, A.: Seabed topography under the southern and western Ronne Ice Shelf, derived from seismic surveys, Antarct.Sci., 9, 201-208, doi:10.1017/S0954102097000254, 1997.

Joughin, I. and Bamber, J.: Thickening of the ice stream catchments feeding the Filchner-Ronne Ice Shelf, Antarctica, Geophys. Res. Lett., 32, L17503, doi:10.1029/2005GL023844, 2005.

Joughin, I. and Padman, L.: Melting and freezing beneath FilchnerRonne Ice Shelf, Antarctica, Geophys. Res. Lett., 30, 1477, doi:10.1029/2003GL016941, 2003.

Joughin, I., Bamber, J. L., Scambos, T., Tulaczyk, S., Fahnestock, M., and MacAyeal, D. R.: Integrating satellite observations with modelling: basal shear stress of the Filcher-Ronne ice streams, Antarctica, Philos. T. Roy. Soc. A, 364, 1795-1814, 2006.

Joughin, I., Smith, B. E., and Holland, D. M.: Sensitivity of 21st century sea level to ocean-induced thinning of Pine Island Glacier, Antarctica, Geophys. Res. Lett., 37, L20502, doi:10.1029/2010GL044819, 2010.

Larour, E., Seroussi, H., Morlighem, M., and Rignot, E.: Continental scale, high order, high spatial resolution, ice sheet modeling using the Ice Sheet System Model (ISSM), J. Geophys. Res., 117, F01022, doi:10.1029/2011JF002140, 2012.

Le Brocq, A. M., Payne, A. J., and Vieli, A.: An improved Antarctic dataset for high resolution numerical ice sheet models (ALBMAP v1), Earth Syst. Sci. Data, 2, 247-260, doi:10.5194/essd-2-247-2010, 2010.
Ligtenberg, S. R. M., van de Berg, W. J., van den Broeke, M. R., Rae, J. G. L., and van Meijgaard, E.: Future surface mass balance of the Antarctic ice sheet and its influence on sea level change, simulated by a regional atmospheric climate model, Clim. Dynam., 41, 867-884, doi:10.1007/s00382-013-1749-1, 2013.

MacAyeal, D. R.: A tutorial on the use of control methods in icesheet modeling, J. Glaciol., 39, 91-98, 1993.

Mercer, J. H.: West Antarctic ice sheet and $\mathrm{CO}_{2}$ greenhouse effect: a threat of disaster, Nature, 271, 321-325, doi:10.1038/271321a0, 1978.

Naish, T., Powell, R., Levy, R., Wilson, G., Scherer, R., Talarico, F., Krissek, L., Niessen, F., Pompilio, M., Wilson, T., Carter, L., DeConto, R., Huybers, P., McKay, R., Pollard, D., Ross, J., Winter, D., Barrett, P., Browne, G., Cody, R., Cowan, E., Crampton, J., Dunbar, G., Dunbar, N., Florindo, F., Gebhardt, C., Graham, I., Hannah, M., Hansaraj, D., Harwood, D., Helling, D., Henrys, S., Hinnov, L., Kuhn, G., Kyle, P., Läufer, A., Maffioli, P., Magens, D., Mandernack, K., McIntosh, W., Millan, C., Morin, R., Ohneiser, C., Paulsen, T., Persico, D., Raine, I., Reed, J., Riesselman, C., Sagnotti, L., Schmitt, D., Sjunneskog, C., Strong, P., Taviani, M., Vogel, S., Wilch, T., and Williams, T.: Obliquitypaced Pliocene West Antarctic ice sheet oscillations, Nature, 458, 322-328, doi:10.1038/nature07867, 2009.

Pattyn, F.: Antarctic subglacial conditions inferred from a hybrid ice sheet/ice stream model, Earth Planet. Sc. Lett., 295, 451, doi:10.1016/j.eps1.2010.04.025, 2010.

Pattyn, F., Huyghe, A., De Brabander, S., and De Smedt, B.: Role of transition zones in marine ice sheet dynamics, J. Geophys. Res., 111, F02004, doi:10.1029/2005JF000394, 2006.

Pattyn, F., Perichon, L., Durand, G., Favier, L., Gagliardini, O., Hindmarsh, R. C., Zwinger, T., Albrecht, T., Cornford, S., Docquier, D., Fürst, J. J., Goldberg, D., Gudmundsson, G. H., Humbert, A., Hütten, M., Huybrechts, P., Jouvet, G., Kleiner, T., Larour, E., Martin, D., Morlighem, M., Payne, A. J., Pollard, D., Rückamp, M., Rybak, O., Seroussi, H., Thoma, M., and Wilkens, N.: Grounding-line migration in plan-view marine icesheet models: results of the ice2sea MISMIP3d intercomparison, J. Glaciol., 59, 410-422, doi:10.3189/2013JoG12J129, 2013.

Payne, A. J., Vieli, A., Shepherd, A. P., Wingham, D. J., and Rignot, E.: Recent dramatic thinning of largest West Antarctic ice stream triggered by oceans, Geophys. Res. Lett. 31, L23401, doi:10.1029/2004GL021284, 2004.

Pollard, D. and DeConto, R. M.: Modelling West Antarctic ice sheet growth and collapse through the past five million years, Nature, 458, 329-332, doi:10.1038/nature07809, 2009.

Pritchard, H. D., Ligtenberg, S. R. M., Fricker, H. A., Vaughan, D. G., van den Broeke, M. R., and Padman, L.: Antarctic icesheet loss driven by basal melting of ice shelves, Nature, 484 , 502-505, doi:10.1038/nature10968, 2012.

Rignot, E. and Jacobs, S. S.: Rapid Bottom Melting Widespread near Antarctic Ice Sheet Grounding Lines, Science, 296, 2020-2023, doi:10.1126/science.1070942, 2002.

Rignot, E., Mouginot, J., and Scheuchl, B.: Ice Flow of the Antarctic Ice Sheet, Science, 333, 1427-1430, doi:10.1126/science.1208336, 2011.

Ross, N., Bingham, R. G., Corr, H. F. J., Ferraccioli, F., Jordan, T. A., Le Brocq, A., Rippin, D. M., Young, D., Blankenship, D. D., and Siegert, M. J.: Steep reverse bed slope at the grounding 
line of the Weddell Sea sector in West Antarctica, Nat. Geosci., 5, 393-396, doi:10.1038/ngeo1468, 2012.

Ross, N., Jordan, T. A., Bingham, R. G., Corr, H. F. J., Ferraccioli, F., Le Brocq, A., Rippin, D. M., Wright, A. P., and Siegert, M. J.: The Ellsworth Subglacial Highlands: Inception and retreat of the West Antarctic Ice Sheet, Bull. Geol. Soc. Am., 126, 3-15, doi:10.1130/B30794.1, 2014.

Scambos, T. A., Bohlander, J., Shuman, C., and Skvarca, P.: Glacier acceleration and thinning after ice shelf collapse in the Larsen B embayment, Antarctica, Geophys. Res. Lett., 31, L18 402, doi:10.1029/2004GL020670, 2004.

Schoof, C.: Ice sheet grounding line dynamics: Steady states, stability, and hysteresis, J. Geophys. Res., 112, F03S28, doi:10.1029/2006JF000664, 2007.

Schoof, C. and Hindmarsh, R. C. A.: Thin-Film Flows with Wall Slip: An Asymptotic Analysis of Higher Order Glacier Flow Models, Q. J. Mech. Appl. Math., 63, 73-114, doi:10.1093/qjmam/hbp025, 2010.
Seroussi, H., Morlighem, M., Rignot, E., Larour, E., Aubry, D., Ben Dhia, H., and Kristensen, S. S.: Ice flux divergence anomalies on 79north Glacier, Greenland, Geophys. Res. Lett., 38, L09501, doi:10.1029/2011GL047338, 2011.

Uotila, P., Lynch, A. H., Cassano, J. J., and Cullather, R. I.: Changes in Antarctic net precipitation in the 21 st century based on Intergovernmental Panel on Climate Change (IPCC) model scenarios, J. Geophys. Res., 112, D10107, doi:10.1029/2006JD007482, 2007.

van den Broeke, M.: Depth and density of the Antarctic firn layer, Arct. Antarct. Alp. Res., 40, 432-438, 2008.

Vieli, A. and Payne, A. J.: Assessing the ability of numerical ice sheet models to simulate grounding line migration, J. Geophys. Res., 110, F01003, doi:10.1029/2004JF000202, 2005.

Winkelmann, R., Levermann, A., Martin, M. A., and Frieler, K.: Increased future ice discharge from Antarctica owing to higher snowfall, Nature, 492, 239-242, doi:10.1038/nature11616, 2012. 